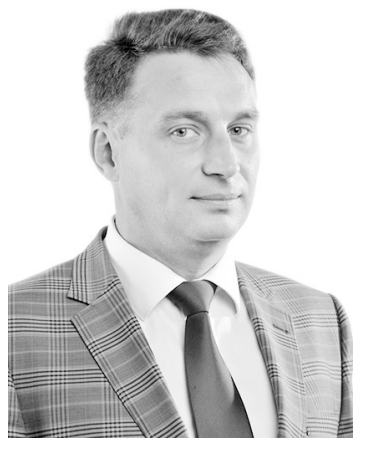

\title{
ПРАВИЛО «ПЛОДІВ ОТРУЕНОГО ДЕРЕВА»: ДОКТРИНАЛЬНІ ПЦДХОДИ ДО ВИЗНАЧЕННЯ, НОРМАТИВНЕ ЗАКРІПЛЕННЯ ТА ПРАКТИКА ЗАСТОСУВАННЯ
} кримінального процесу та криміналістики Київського національного університету імені Тараса Шевченка

DOI 10.32782/EP.2021.4.9

Статья посвящена раскрьттию на основе норм Уголовного процессуального кодекса Украинъи и с учетом практики Европейского суда по правам человека и Верховного Суда содержания правила «плодов отравленного дерева» и механизма его применения в отечественном уголовном процессе.

Исследованъ сбормированнвие в доктрине уголовного процесса подходъ к пониманию содержания правила «плодов отравленного дерева»: широкий и узкий. Обосновано, ито правило «плодов отравленного дерева» подлежит применению в узком понимании, при котором $\kappa$ признанию доказательств недопустимылми на его основе должнъ приводить лишь существеннъе нарушения требований уголовного процессуального закона, допущеннъие при получении доказательств.

Указано, ито применение правила плодов отравленного дерева отечественнълм судами осуществляется с учетом практики ЕСПЧ. На основе ряда решений ЕСПЧ раскрътть его подходъ к применению правила «плодов отравленного дерева». С учетом ряда постановлений ВС въделенъ его въгоды о содержании и механизме применения правила «плодов отравленного дерева».

По результатам исследования приведено определение правила «плодов отравленного дерева", под которьм предложено понимать совокупность нормативно закрепленных и наработаннъхх в судебной практике положений, которье определяют получение доказа- тельств на основе незаконно полученной информачии как основание признания таких доказательств недопустимьлми, раскрьввают содержание этого основания и предусматривают механизм принятия соответствующего процессуального решения. С целью предотвращения буквального толкования нормативного содержания правила «плодов отравленного дерева» предложено внести соответствующие дополнения в часть 1 статьи 87 УПК Украинъг.

Ключевъе слова: доказательства, допустимость доказательств, признание доказательств недопустимьлми, правило «плодов отравленного дерева», правило «неизбежного обнаружения».

\section{Постановка проблеми}

Здійснення оцінки доказу з точки зору допустимості спрямоване на встановлення дотримання вимог кримінального процесуального закону під час його отримання. Як передбачає частина 1 статті 86 Кримінального процесуального кодексу України (далі - КПК України), доказ визнається допустимим, якщо він отриманий у порядку, встановленому цим Кодексом [5]. I, навпаки, недотримання вимог кримінального процесуального закону щодо порядку отримання доказу призводить до його визнання недопустимим із застосуванням відповідних процесуальних наслідків, визначених КПК України. 


\section{Кримінальне право, кримінальний процес та криміналістика}

Один із таких наслідків передбачений низкою положень кримінального процесуального закону, з урахуванням яких докази, отримані на основі незаконно здобутої інформації, підлягають визнанню недопустимими. Зазначена підстава визнання доказів недопустимими у доктрині кримінального процесу визначається як правило «плодів отруєного дерева» (doctrine of the «fruit of the poisonous tree») та знайшла широке використання в судовій практиці як Европейського суду $з$ прав людини (далі - ЕСП $\Lambda$ ), так і національних судів, у тому числі Верховного Суду (далі - ВС).

\section{Аналіз останніх досліджень і публікацій}

Зміст правила «плодів отруєного дерева» та механізм його застосування були предметом дослідження широкого кола вітчизняних і зарубіжних вчених. Так, до розкриття цієї проблематики зверталися Н.М. Басай, М.В. Гузела, О.М. Дроздов, О.В. Дроздова, О.В. Капліна, С.О. Ковальчук, Г.Р. Крет, А.А. Павлишин, М.М. Стоянов, Ю.В. Циганюк, О.Г. Шило, О.Г. Яновська та інші науковці, які в переважній більшості досліджували окремі іiі теоретичні та практичні аспекти, у тому числі й у контексті практики $\mathrm{ECП} \wedge$ і ВС. Наукові праці вказаних та інших вчених закладають теоретичне підгрунтя для здійснення комплексного дослідження правила «плодів отруєного дерева» у вітчизняному кримінальному процесі.

Метою статті $\epsilon$ розкриття на основі норм КПК України та з урахуванням практики ЕСПл і ВС змісту правила «плодів отруєного дерева» та механізму його застосування у вітчизняному кримінальному процесі. Необхідність досягнення цієї мети зумовлює потребу у вирішенні завдань, пов'язаних із визначенням змісту вказаного правила, розкриттям його нормативного змісту та механізму застосування, окресленням напрямів удосконалення КПК України у частині визначення його змісту.

Виклад основного матеріалу

У доктрині кримінального процесу сформувалося два підходи до розуміння змісту правила «плодів отруєного дерева»: широкий і вузький.

Прихильники широкого підходу відзначають абсолютний характер цього правила незалежно від істотності порушень вимог кримінального процесуального закону, допущених під час отримання доказів. Надаючи тлумачення правилу «плодів отруєного дерева» у широкому розумінні, М.М. Стоянов констатує, що воно означає безумовну недопустимість доказів при будь-якому порушенні встановленого порядку збирання доказів незалежно від характеру і ступеня [14, с. 119-120]. У цьому разі, як зазначає H.M. Басай, «отруєне дерево» породжує «отруєні плоди»; отримання доказів на основі інформації, яка отримана із недопустимого доказу, тягне за собою їх безумовну недопустимість [1, с. 44].

Прихильники вузького підходу вказують на неможливість визнання правила «Плодів отруєного дерева» абсолютним i необхідність урахування істотності порушень вимог кримінального процесуального закону, допущених під час отримання доказів. Як наголошує М.М. Стоянов, у вузькому сенсі доктрина «плодів отруєного дерева» зводиться до заборони використання даних, отриманих на підставі або з використанням доказів, визнаних недопустимими. Тобто в другому значенні доктрина пов'язується 3 проблемою використання доказів, хоча і законних за формою, але збиткових за змістом [14, с. 121]. Поділяючи таку позицію, М.В. Гузела відзначає, що у вузькому розумінні концепцію «плодів отруйного дерева» потрібно подавати $з$ погляду способу отримання доказів, їхнього процесуального оформлення та диференціації процесуальних порушень на істотні та неістотні [2, с. 427].

Аналізуючи наведені підходи, потрібно вказати, що за першого з наведених підходів до визнання доказів недопустимими на основі правила «плодів отруєного дерева» можуть призводити будь-які порушення вимог кримінального процесуального закону, які були допущені в ході отримання доказів, у тому числі неістотні. Водночас, такий підхід не відповідає закладеній законодавцем у КПК України концепції допустимості доказів. 
По-перше, у цілому зміст правила «плодів отруєного дерева» визначається у частині 1 статті 87 КПК України, відповідно до якої будь-які докази, здобуті завдяки інформації, отриманій внаслідок істотного порушення прав та свобод людини, підлягають визнанню недопустимими [5]. Тобто законодавець прямо вказує на абсолютний характер зазначеного правила лише у випадках встановлення істотного порушення прав і свобод людини, допущеного під час одержання інформації, на основі якої у подальшому були отримані інші докази. Коло діянь, які становлять істотні порушення прав людини і основоположних свобод, визначається в частині 2 статті 87 КПК України.

По-друге, застосування правила «плодів отруєного дерева» не обмежується випадками, визначеними у частині 1 статті 87 КПК України, та є можливим у разі допущення інших порушень вимог кримінального процесуального закону, які мали місце в ході отримання доказів і призвели до визнання ïх недопустимими. Такі порушення визначені частиною 3 статті 87 та іншими положеннями КПК України, які прямо або опосередковано передбачають підстави визнання доказів недопустимими (частиною 5 статті 101 , частиною 8 статті 223, частиною 3 статті 233, частиною 3 статті 271). У наведених положеннях кримінального процесуального закону, на відміну від частини 1 статті 87 КПК України, не міститься прямої вказівки на істотність допущених під час отримання доказів порушень, хоча про визнання законодавцем вказаних у частині 3 статті 87 КПК України порушень істотними свідчить положення частини 4 цієї статті, а про визнання такими порушень, передбачених частиною 5 статті 101 , частиною 8 статті 223 , частиною 3 статті 233, частиною 3 статті 271 КПК України, - їх характер, що зумовив необхідність їх нормативного закріплення як самостійних підстав визнання доказів недопустимими.

Відповідно, для визнання доказів недопустимими на основі правила «плодів отруєного дерева» потрібно встановити істотність порушень вимог кримінального процесуального закону, допущених під час одержання інформації, на основі якої в подальшому були отримані докази. Як зазначає А.В. Панова, у кожному конкретному випадку суд, оцінюючи допустимість того чи іншого доказу, повинен враховувати істотність допущених порушень кримінального процесуального закону та важливість кожного доказу для встановлення обставин кримінального провадження. Тому кожний доказ повинен оцінюватися автономно, оскільки його безумовне виключення може призвести до негативних наслідків, що виражатимуться в ухваленні незаконного, необгрунтованого та несправедливого судового рішення [6, с. 51].Із урахуванням наведеного заслуговує на підтримку другий із наведених підходів до визнання доказів недопустимими на основі правила «плодів отруєного дерева», за якого призводити до прийняття такого рішення повинні лише істотні порушення вимог кримінального процесуального закону, допущені під час отримання доказів.

Застосування правила «плодів отруєного дерева» вітчизняними судами здійснюється 3 урахуванням практики $\mathrm{ECПл,} \mathrm{який} \mathrm{у} \mathrm{разі}$ констатації порушення статті 3 Конвенції про захист прав та основоположних свобод від 04.11.1950 р. (далі - Конвенція), як констатує Г.Р. Крет, звертається до встановлення правильності наданої національними судами оцінки з точки зору допустимості доказам, отриманим на підставі доказу, визнаного недопустимим, і за загальним правилом застосовує в цих ситуаціях правило «плодів отруєного дерева» [4, с. 209-210]. Так, у §§ 65 і 66 рішення від 30.04.2015 р. у справі «Яременко проти України (№ 2)» ЄСП рює свої основні висновки з рішення у справі «Яременко проти України», а саме: що попередні рішення, якими заявника було засуджено за двома епізодами умисних вбивств, грунтувалися на доказовій базі, отриманій у порушення права заявника на мовчання та його права на захист, а також за відсутності належного розслідування його тверджень про те, що його визнавальні показання було отримано в незаконний спосіб. Нове рішення, ухвалене у справі заявника, переважною мірою знову грунтувалося на тих самих доказах, отриманих у порушення процесуальних прав заявника, та при цьому існували серйозні твердження, які органи влади так 


\section{Кримінальне право, кримінальний процес та криміналістика}

і не спростували, що всі визнавальні показання було отримано під примусом, а отже вони були «плодом отруйного дерева» [13].

У подальшому ЕСП $\wedge$ у своїй практиці визнав необхідність застосування правила «плодів отруєного дерева» до доказів, отриманих внаслідок катування або нелюдського чи такого, що принижує гідність, поводження не лише державними органами, але й приватними особами. Так, у $\S 75-77,89$ - 93 рішення від 05.11.2020 р. у справі «С́wik

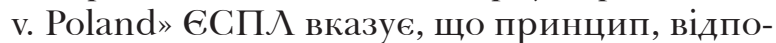
відно до якого визнання показань і речових доказів, отриманих у результаті катування або іншого жорстокого поводження в порушення статті 3 Конвенції, доказом для встановлення відповідних фактів у кримінальному провадженні робить провадження в цілому несправедливим, застосовуються не тільки у випадках, коли жертвою поводження, яке суперечить статті 3 Конвенції, є фактичний обвинувачений, але й у випадку, коли йдеться про третіх осіб. Суд вважає, що вищезгаданий принцип є однаково застосовним до визнання доказів, отриманих від третьої сторони у результаті жорстокого поводження, забороненого статтею 3 Конвенції, коли таке жорстоке поводження було завдано приватними особами, незалежно від виду цього ставлення. Суд вважає, що визнання оскаржуваного протоколу (протоколу, який містив розшифровки записаних внаслідок застосування катування висловлювань іншого члена злочинного угрупування, підтверджував причетність заявника до цього угруповання та торгівлі наркотичними засобами і був використаний стороною обвинувачення під час судового розгляду заявника - В.Г.) доказом у кримінальному провадженні проти заявника в цілому зробило провадження несправедливим, порушуючи пункт 1 статті 6 Конвенції [15].

За загальним правилом, напрацьованим у практиці ЄСП $\curlywedge$, констатація порушення статті 3 Конвенції та застосування правила «плодів отруєного дерева» до доказів, отриманих внаслідок катування або іншого жорстокого поводження, призводить до визнання провадження у справі несправедливим у цілому. Водночас, як вказує С.О. Ковальчук, у судовій практиці ЄСП отруєного дерева» не завжди надається абсолютного значення [3, с. 343]. Виняток із загального правила простежується, зокрема, у $\S \S 169$ - 191 рішення від 01.06.2010 р. у справі «Gäfgen v. Germany», в якому ЄСП вказує, що за конкретних обставин справи саме нове зізнання заявника під час судового засідання було основою для його засудження. Інші докази, включаючи оскаржувані речові докази, мали лише допоміжний характер i на них покладалися лише для підтвердження правдивості цього зізнання. Здійснивши аналіз обставин справи і погоджуючись з висновками Палати, Суд дійшов висновку, що оспорювані речові докази не були необхідними і не використовувалися для доведення вини заявника. Водночас у причинно-наслідковому ланцюзі, який веде від заборонених методів розслідування до засудження заявника, стосовно оскаржуваних речових доказів відбувся розрив. Проте у конкретних обставинах справи заявника невиключення оскаржених речових доказів, отриманих на основі його заяв, здійснених внаслідок нелюдського поводження, не впливало на засудження заявника. Оскільки право заявника на захист і його право не свідчити проти себе так само було дотримано, судовий розгляд у цілому повинен вважатися справедливим. Відповідно, порушення пунктів 1 і 3 статті 6 Конвенції не було [16].

Поряд із цим, ЄСПЛ звертає увагу на можливість застосування національними судами винятків із правила «плодів отруєного дерева», які передбачені нормами національного законодавства або випливають 3 його тлумачення. Водночас, ЕСП н не звертається до надання оцінки таким виключенням, якщо вони не були предметом дослідження національних судів. Так, у § 49 рішення від 22.05.2018 р. у справі «Svetina v. Slovenia» вказує на правило «неминучого виявлення» («inevitable discovery doctrine») i зазначає, що суть скарги заявника полягає в незгоді з правовою оцінкою національних судів щодо допустимості доказів, яка в основному грунтується на думці, що докази, які отримані в ході незаконного огляду або обшуку, але були б неминуче виявлені навіть за відсутності такого огляду, можуть бути допущені до кримінальної справи. Проте ця 
незгода стосується питання тлумачення національного законодавства, яке, передусім, має вирішуватися національними судами. Відповідно, Суд не робить жодного висновку щодо відповідності доктрини «неминучого виявлення» вимогам Конвенції.

Правило «плодів отруєного дерева» широко використовується у практиці ВС (у якій воно іменується доктриною), яким напрацьовано такі висновки щодо його змісту та механізму застосування:

1) ця доктрина передбачає заборону використання даних, отриманих на підставі або з використанням доказів, визнаних недопустимими (постанова Касаційного кримінального суду (далі - ККС) у складі ВС від 30.05.2019 р. у справі № 164/1457/16-к) [11], а під час перегляду справи за особливими обставинами, зокрема, на підставі встановлення міжнародною судовою установою, юрисдикція якої визнана Україною, порушення державою міжнародних зобов'язань при вирішенні справи судом, зміст цієї доктрини полягає в недопустимості доказів, похідних від джерел, отриманих усупереч вимогам Конвенції (постанова Великої Палати (далі - ВП) ВС від 09.09.2020 р. у справі№ 1-27/10) [9], тобто якщо джерело доказів є недопустимим, усі інші дані, одержані з його допомогою, будуть такими ж (постанова ВП ВС від 06.07.2021 р. у справі № 1-7/2010) [10];

2) зазначена доктрина передбачає оцінку не лише кожного засобу доказування автономно, а і всього ланцюга безпосередньо пов язаних між собою доказів, 3 яких одні випливають 3 інших та є похідними від них (постанова ВП ВС від 13.11.2019 р. у справі № 1-07/07) [7];

3) критерієм віднесення доказів до «плодів отруєного дерева» $є$ наявність достатніх підстав вважати, що відповідні відомості не були 6 отримані за відсутності інформації, одержаної незаконним шляхом (постанова ВП ВС від 09.09.2020 р. у справі № 1-27/10) [9];

4) застосування правила «плодів отруєного дерева» вимагає здійснення логічних операцій щодо встановлення джерела походження інформації, завдяки якій було здобуто кожен доказ, яким обгрунтовується судове рішення (постанова ВП ВС від 29.04.2020 р. у справі № 1-305/2009) [8];
5) стосовно визнання доказу недопустимим за правилом «плодів отруєного дерева», то у рішенні суду має бути чітко доведено похідний характер інформації, яка стала фактичною підставою для проведення відповідної слідчої (розшукової) дії, від дій, якими були істотно порушені права та свободи людини (постанова ККС ВС від 04.02.2020 р. у справі № 311/1110/18) [12];

6) відділяючи докази, здобуті завдяки інформації, отриманій внаслідок істотних порушень прав і свобод людини, встановлених рішенням $\mathrm{ECП} \Lambda$, від доказів, отриманих 3 джерел, не пов'язаних ані прямо, ані опосередковано із такою інформацією, суд 3 повноваженнями касаційної інстанції здійснює перевірку правильності правової оцінки обставин та допустимості кожного окремого доказу (постанова ВП ВС від 29.04.2020 р. у справі № 1-305/2009) [8];

7) зазначені логічні операції не потребують здійснення дослідження доказів та не обумовлюють необхідність здійснення переоцінки достовірності доказів, які все ж були визначені як такі, що можуть бути покладені в основу судового рішення і використані на підтвердження доведеності вини заявника в інкримінованих йому кримінальних правопорушеннях (постанова ВП ВС від 29.04.2020 р. у справі № 1-305/2009) [8];

8) у разі застосування доктрини «Плодів отруєного дерева» однією 3 необхідних умов, при дотриманні яких видається можливим зміна судового рішення при перегляді справи за особливими обставинами, зокрема, на підставі встановлення міжнародною судовою установою, юрисдикція якої визнана Україною, порушення державою міжнародних зобов'язань при вирішенні справи судом, належить така: сукупність доказів, що залишились після виключення з обсягу доказової бази доказів, отриманих внаслідок істотного порушення прав та свобод людини, а також тих доказів, що були отримані завдяки інформації з таких джерел, є достатньою для підтвердження доведеності вини заявника в інкримінованих йому кримінальних правопорушеннях (постанова ВП ВС від 09.09.2020 р. у справі№ 1-27/10) [9]. 


\section{Висновки}

Проведене дослідження свідчить, що правило «плодів отруєного дерева» є сукупністю нормативно закріплених і напрацьованих у судовій практиці положень, які визначають отримання доказів на основі незаконно здобутої інформації як підставу визнання таких доказів недопустимими, розкривають зміст цієї підстави і передбачають механізм ухвалення відповідного процесуального рішення. Правило «плодів отруєного дерева» підлягає застосуванню у вузькому розумінні, за якого до визнання доказів недопустимими на його основі повинні призводити лише істотні порушення вимог кримінального процесуального закону, допущені під час отримання доказів. Необхідність запобігання буквальному тлумаченню нормативного змісту правила «плодів отруєного дерева» свідчить про доцільність доповнення частини 1 статті 87 КПК України після слів «отриманій внаслідок істотного порушення прав та свобод людини» словами «або будь-яких інших істотних порушень вимог цього Кодексу».

\section{Аітература}

1. Басай Н.М. Визнання доказів недопустимими в кримінальному процесі України: підстави, процесуальний порядок і правові наслідки: дис. ... канд. юрид. наук: 12.00.09. Одеса, 2012. 264 с.

2. Гузела М. Проблема визнання доказів недопустимими у кримінальному провадженні. Вісник Аьвівського університету. Серія юридична. 2015. Вип. 61. С. 423-434.

3. Ковальчук С.О. Вчення про речові докази у кримінальному процесі: теоретико-правові та практичні основи: монографія. Івано-Франківськ: Супрун В.П., 2017. $618 \mathrm{c}$.

4. Крет Г.Р. Міжнародні стандарти доказування у кримінальному процесі України: теоретико-правові та практичні основи: монографія. Калуш: Петраш К.Т., 2020. 452 c.

5. Кримінальний процесуальний кодекс України від 13.04.2012 р. № 4651-VI. URL: http://zakon.rada.gov.ua/laws/show/4651-17.
6. Панова А.В. Визнання доказів недопустимими у кримінальному провадженні: дис. ... канд. юрид. наук: 12.00.09. Х., 2016. $226 \mathrm{c}$.

7. Постанова ВП ВС від 13.11.2019 р. у справі № 1-07/07 (провадження № 1336зво19). URL: https://reyestr.court.gov.ua/ Review/85869105

8. Постанова ВП ВС від 29.04.2020 р. у справі № 1-305/2009 (провадження № 1397зво19). URL: https://reyestr.court.gov.ua/ Review/89180571.

9. Постанова ВП ВС від 09.09.2020 р. у справі № 1-27/10 (провадження № 1322зво20). URL: https://reyestr.court.gov.ua/ Review/91572019.

10. Постанова ВП ВС від 06.07.2021 p. у справі № 1-7/2010 (провадження № 133зво21). URL: https://reyestr.court.gov.ua/ Review/98327550.

11. Постанова ККС ВС від 30.05.2019 p. у справі № 164/1457/16-к (провадження№ 51-8008км18). URL: https://reyestr.court. gov.ua/Review/82261840.

12. Постанова ККС ВС від 04.02.2020 р. у справі № 311/1110/18 (провадження № 514150км19). URL: https://reyestr.court.gov.ua/ Review/87517442.

13. Справа «Яременко проти України (№ 2)»: рішення Європейського суду з прав людини від 30.04.2015 p. URL: https://zakon. rada.gov.ua/laws/show/974_a75.

14. Стоянов М.М. Властивості доказів у кримінальному процесі України: дис. ... канд. юрид. наук. Одеса, 2010. 245 с.

15. Case of Ćwik v. Poland: Judgment of the European Court of Human Rights from 5 November 2020. URL: http://hudoc.echr.coe. int/eng? $\mathrm{i}=001-205536$.

16. Gäfgen v. Germany: Judgment of the European Court of Human Rights from 1 June 2010. URL: http://hudoc.echr.coe.int/ tur?i=001-99015.

17. Case of Svetina v. Slovenia: Judgment of the European Court of Human Rights from 22 May 2018. URL: http://hudoc.echr.coe.int/ eng? $\mathrm{i}=001-183124$. 


\section{АНОТАЦІЯ}

Стаття присвячена розкриттю на основі норм Кримінального прочесуального кодексу Украӥни та з урахуванням практики Европейсъкого суду з прав людини $і$ Верховного Суду змісту правила «плодів отруєного дерева» та механізму його застосування у вітиизняному кримінальному процесі.

Досліджено сбормовані в доктрині кримінального процесу підходи до розуміння змісту правила «плодів отруєного дерева»: широкий $i$ вузький. Обгрунтовано, що правило «плодів отруєного дерева» підлягає застосуванню у вузькому розумінні, за якого до визнання доказів недопустимими на його основі повинні призводити лише істотні порушення вимог кримінального прочесуального закону, допущені під час отримання доказів.

Вказано, що застосування правила «плодів отруєного дерева» вітчизняними судами здійснюється з урахуванням практики ЕСПА. На основі низки рішень ЕСПЛ розкрито його підходи до застосування правила «плодів отруєного дерева». Із урахуванням низки постанов ВС виокремлено його висновки щодо змісту та механізму застосування правила «плодів отруєного дерева».

За результатами дослідження наведено визначення правила «плодів отруєного дерева», під яким запропоновано розуміти сукупність нормативно закріплених $i$ напращъованих у судовій практиці положень, які визначають отримання доказів на основі незаконно здобутої інбормаиіӥ як підставу визнання таких доказів недопустимими, розкривають зміст иієї підстави $i$ передбачають механізм ухвалення відповідного процесуального рішення. 3 метою запобігання буквальному тлумаченню нормативного змісту правила «плодів отруєного дерева» запропоновано внести відповідні доповнення до частини 1 статті 87 КПК України.

Ключові слова: докази, допустимість доказів, визнання доказів недопустимими, правило «плодів отруєного дерева», правило «неминучого виявлення».

\section{SUMMARY}

The article is devoted to disclosure on the basis of the Criminal Procedure Code of Ukraine and taking into account the case law of the European Court of Human Rights and the Supreme Court of the content of the doctrine of the "fruit of the poisonous tree» and the mechanism of its application in domestic criminal proceedings.

The approaches to understanding the meaning of the doctrine of the "fruit of the poisonous tree» formed in the doctrine of the criminal process are studied: wide and narrow. It is substantiated that the doctrine of the "fruit of the poisonous tree» is subject to application in the narrow sense, according to which only significant violations of the requirements of the criminal procedure law committed during the collection of evidence should lead to the recognition of evidence inadmissible on its basis.

It is stated that the application of the doctrine of the "fruit of the poisonous tree» by domestic courts is carried out taking into account the practice of the ECHR. Based on a number of ECHR decisions, his approaches to the application of the doctrine of the "fruit of the poisonous tree» are revealed. Taking into account a number of resolutions of the Supreme Court, its conclusions on the content and mechanism of application of the doctrine of the "fruit of the poisonous tree» are highlighted.

According to the results of the study, the doctrine of the "fruit of the poisonous tree» is defined and it is proposed to understand as a set of normatively established and developed in judicial practice provisions that determine the receipt of evidence on the basis of illegally obtained information as grounds for declaring such evidence inadmissible, disclose the content of this ground and provide a mechanism for making the appropriate procedural decision. In order to prevent a literal interpretation of the normative content of the doctrine of the "fruit of the poisonous tree» it is proposed to make appropriate additions to Part 1 of Article 87 of the CPC of Ukraine.

Key words: evidence, admissibility of evidence, recognition of evidence inadmissible, doctrine of the "fruit of the poisonous tree», «inevitable discovery doctrine». 